Copyright (C) 2021 by Cherkas Global University

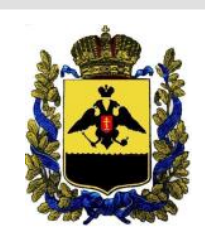

Published in the USA

Bylye Gody

Has been issued since 2006.

E-ISSN: $2310-0028$

2021. 16(4): 2063-2072

DOI: $10.13187 / \mathrm{bg} .2021 .4 .2063$

Journal homepage:

https://bg.cherkasgu.press

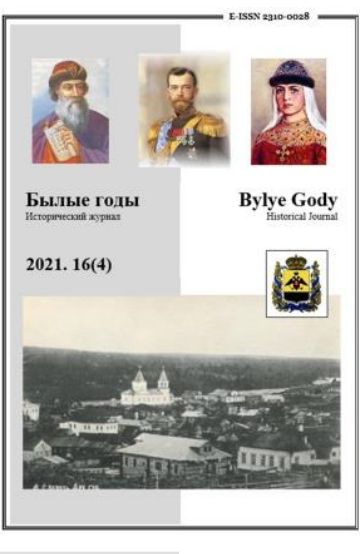

\title{
Patriotic Moods of 1914 as a Mobilization Resource of Social Transformations
}

Pavel A. Merkulov a, Svetlana V. Bukalova a, *, Oksana V. Leonova b, Nadezhda V. Mironenko a

${ }^{a}$ Russian Presidential Academy of National Economy and Public Administration, branch of the Central Russian Institute of administration, Russian Federation

b Bank College of the Central Russian Institute of administration - Russian Presidential Academy of National Economy and Public Administration branch, Russian Federation

\begin{abstract}
The article analyzes the "patriotic upsurge" that accompanied Russia's entry into the World War I. This phenomenon of public consciousness and mass behavior is considered within the framework of the prerevolutionary evolution of the socio-political sphere in the Russian Empire, which demonstrated the paradoxical dynamics of the transition from the apparent unity of society and authorities to the predominance of anti-autocratic sentiments in the conditions of the external military aggression. The authors points out the weakness of ideological basis of patriotic moods of July-August 1914, which led to the predominance of the emotional component in them and determined the temporary limitation of this phenomenon. The content of the "moods of 1914" is analyzed through their objective external manifestations: patriotic processions, a surge of charity and volunteerism, riots of the mobilized. Each of these phenomena can only be explained to a limited extent by patriotic or "anti-patriotic" motivation. It is concluded that the initial period of the World War I in Russia was accompanied by contrasting manifestations of social activity and opposite emotions, reflecting the transition of society from a stable to an extreme status. The authors come to the conclusion that "patriotic upsurge" by its nature was an independent phenomenon, which allows us to consider it outside of the widespread three-stage periodization of the patriotic sentiments evolution in Russia during the World War I. This point of view removes the problem of the autocracy "guilt", which couldn't use the potential of universal patriotic enthusiasm to mobilize Russian society to the total war.

Keywords: Russian Empire, World War I, patriotism, mobilization, social policy, charity, riots of the mobilized.

\section{1. Введение}

Важным элементом формирующейся политической культуры россиян в первые десятилетия XXI века стал патриотизм. Содержание этого понятия при всей мнимой простоте и ясности его значения как «любви к Родине» остается предметом общественно-политических дискуссий, что актуализирует обращение к историческому дискурсу российского патриотизма, особое место в котором занимает период Первой мировой войны. Начало войны сопровождалось всплеском патриотических настроений, отмечаемых как современниками, так и историками.

Патриотизм представлялся значимым ресурсом общественной мобилизации. Однако в течение войны патриотические настроения претерпели впечатляющую трансформацию: от «патриотического подъема» и единения общества и власти летом 1914 года к «патриотической тревоге» осени 1915 года, «атаке на власть» 1916 года, разворачивавшейся под патриотическими лозунгами и увенчавшейся
\end{abstract}

\footnotetext{
${ }^{*}$ Corresponding author

E-mail addresses: stl1612@yandex.ru (S.V. Bukalova), nio-ranepa57@mail.ru (P.A. Merkulov), oks980@rambler.ru (O.V. Leonova), mironenkonado@mail.ru (N.V. Mironenko) 
падением самодержавия. Весна 1917 года была отмечена новым всплеском лихорадочного «гражданского» патриотизма, на смену которому быстро пришли дезорганизация, анархия, распространение пораженческих настроений. В дальнейших трагических событиях Гражданской войны патриотическую платформу занимал антибольшевистский лагерь, обвинявший большевиков в сговоре с врагом и предательстве интересов России. Таким образом, создается впечатление, что российский патриотизм образца 1914 года не оправдал возлагавшихся на него надежд, не смог сыграть той же мобилизующей и объединяющей роли, что и в других странах-участницах Первой мировой войны. Это вновь привлекает внимание исследователей к анализу особенностей содержания, структуры и факторов трансформации патриотических настроений россиян в годы Великой войны.

\section{2. Материалы и методы}

В основу исследования положен принцип историзма, так как понятие патриотизма многозначно по содержанию и исторично по своей сути. Изучение патриотизма как общественного явления и фактора социального управления соотносится с проблемой формирования государственной идеологии, ее индоктринации в общественное сознание и реализации в практических формах. В то же время патриотизм как феномен массовой психологии и отдельные его проявления могут получить объяснение в рамках социальной антропологии.

Особое место в ретроспективных исследованиях феномена российского патриотизма занимает вступление России в Первую мировую войну. Представляется целесообразным сфокусировать внимание на начальном этапе эволюции патриотических настроений, который стал своеобразным «эталоном» и «точкой отсчета» для дальнейшей трансформации массового сознания. Его анализ осуществлен с опорой на метод конструктивизма, предложенный для исследования данной тематики Н.В. Юдиным и О.А. Суховой (Юдин, 2014; Сухова, 2014). Исторический конструктивизм исходит из признания принципиальной неоднородности коллективных представлений и зависимости их интерпретации от социокультурного контекста (Теория, 2014: 226-229).

Поскольку патриотизм является социально-психологическим феноменом, находящим выражение в индивидуальных и коллективных акциях, стоит задача выделения набора паттернов коллективных действий, которые будут соответствовать специфическим проявлениям массовых настроений лета 1914 года. К таковым мы можем отнести массовые мероприятия (митинги и манифестации, молебны), верноподданнические телеграммы, добровольческое и благотворительное движение, беспорядки среди мобилизованных, «борьбу с германизмом».

Проблемным полем исследования стала провинциальная периферия Европейской России как особая социокультурная среда с преобладавшим сельским населением, менее затронутая процессами модернизации, нежели столицы и крупные города, более однородная в этноконфессиональном отношении. Идеи и настроения, родившиеся в центре, распространяются на провинцию, изменяя ее и искажаясь ею. Провинциальный социум менее инициативен и более консервативен, нежели социальная среда метрополии. Эта особенность накладывала свой отпечаток и на патриотический дискурс начального периода войны.

\section{3. Обсуждение}

Характеристике особой атмосферы, сопровождавшей начало войны, так или иначе уделяют внимание все авторы, исследующие внутриполитическую ситуацию в Российской империи накануне революции - при этом ее оценки могут быть диаметрально противоположными. Уже в работах В.И.Ленина, опубликованных в эмиграции в годы войны, отмечалось, что «война не может не вызывать в массах самых бурных чувств, нарушающих обычное состояние сонной психики» (Ленин, 1969: 290). Среди них, кроме классовой ненависти сознательного пролетариата к буржуазным правительствам, Ленин выделял отчаяние, влекущее оживление религиозных чувств, и ненависть к врагу, искусно формируемую и разжигаемую в обществе. В советский период, следуя ленинским оценкам, всеобщая поддержка вступления России в Великую европейскую войну оценивалась как «шовинистический угар».

В 1990-е годы начался новый период изучения отечественной истории Первой мировой войны, значительно расширилось проблемное поле исследования; в частности, появилось немало работ в рамках локальной истории, основанных на региональных источниках (Белова, 2011; Леонов, 2014; Поршнева, 2014; Семенова, 2011).

Патриотические настроения россиян периода Первой мировой войны могут выступать как самостоятельный предмет исследования или же рассматриваться как элемент эволюции общественных настроений разных социальных слоев предреволюционного периода.

В наиболее широком контексте феномен патриотических настроений и их проявлений связывается с формированием гражданской политической культуры по образцу западных обществ. Такие авторы, как Э. Лор, Дж. Санборн, рассматривают связь патриотизма и идеологии политического национализма (Санборн, 1999; Лор, 2012).

Немаловажное значение в начальный период войны имело форсированное формирование в массовом сознании образа врага, призванное послужить консолидации общества. Стихийные 
антигерманские настроения первых дней войны не только подпитывались пропагандой, но и подкреплялись мерами государственной политики, направленными против подданных враждебных держав и русских подданных немецкого происхождения. Эти действия рассматривались как соответствующие патриотическим запросам масс (Лор, 2012), но в итоге обернулись против самой власти, так как «борьба с германизмом» вылилась в германофобию и шпиономанию, слухи об измене «царицы-немки» (Сергеев, 2020: 49).

В отечественной историографии сложилось два основных подхода к оценке патриотизма: «оптимистический» и «скептический». Представители первого из них, основываясь преимущественно на сообщениях провинциальной прессы, акцентируют внимание на всеобем энтузиазме, снижении конфликтности, «единении общества и власти». С.Н. Базанов, отмечая мощный всенародный порыв и готовность к самопожертвованию, охватившие в начале войны широкие слои общества, указывает также и на то, что его идейным обоснованием, как и у других стран-участниц, стала защита родины, национальных интересов и национальных святынь (Базанов, 2017: 9-10).

Саратовские историки полагают, что наиболее мощный патриотический порыв в 1914 году показало крестьянство, а сами патриотические чувства имели «естественный характер», основанный на желании защитить свое достояние от врага. Критерием крестьянского патриотизма авторы считают успешную мобилизацию (Демидова и др., 2018: 66).

«Скептическая» линия историографии проблемы, базируясь на привлечении личных свидетельств очевидцев из дневников, переписки и мемуаров, позволяет выявить внутреннюю противоречивость «патриотического подъема», который порой может представать своей противоположностью.

Так, В.П. Булдаков трактует «настроение 1914 г.» как шовинистическую перверсию устоявшихся форм общественного недовольства, а революционные настроения, в свою очередь, называет извращением патриотизма (Булдаков, 2014: 12, 18). По мнению В.Б. Аксенова, «уместно говорить о психопатологической форме патриотизма (в случаях, когда основанный на страхе и ненависти патриотизм разрушал психику субъекта)». Автор утверждает, что «токсический уровень патриотизма оборачивался психическими отклонениями» (Аксенов, 2018: 242). Однако утверждение автора о всплеске психических заболеваний, сопровождавшем патриотический подъем, опровергается фактами (Сироткина, 2007: 341; Асташов, 2014: 342-343). Такое утверждение больше, чем заблуждение: оценка неких событий как причины болезни означает одновременно и моральное осуждение таких событий.

Если первое направление не принимает во внимание фактор подцензурности печати, то второе - зачастую игнорирует субъективность и фрагментарность индивидуальных оценок происходящего. Кроме того, в арсенале исследователей чаще всего оказываются свидетельства авторов, принадлежащих к элитным столичным кругам (или во всяком случае - к верхним социальным слоям) российского общества.

Начиная, по крайней мере, со статьи И.П. Лейберова, получила распространение трехчастная периодизация патриотических настроений российского общества в годы Первой мировой войны, обрывающаяся на Февральской революции. Первый этап представлен как консолидация вокруг трона и армии в надежде на победоносное завершение войны; второй - после Великого отступления описывается как «растерянность» общества, упадок веры в самодержавие. Наконец, третий, самый короткий (ноябрь 1916 - февраль 1917 года), - характеризуется нарастанием антивоенных и революционных настроений (Лейберов, 1999: 498).

Нередко применительно к периоду Первой мировой войны противопоставляются «имперский» и «гражданский» патриотизм, констатируется нарастающий разрыв в понимании патриотизма правящими и оппозиционными кругами. Е.Ю. Семенова, исследуя трансформацию патриотических настроений городского населения Поволжья, разделяет «стихийный» патриотизм народных масс и «осознанный» патриотизм образованной публики. Первый - под влиянием испытаний военного времени эволюционировал в сторону пацифизма, тогда как второй - революционного оборончества (Семенова, 2011).

Возникает своеобразный парадокс: единение общества и власти, энтузиазм по поводу вступления в войну обернулись своими противоположностями. По мнению И.Л. Архипова, фактор патриотизма послужил почвой для политических спекуляций как власти, так и либеральной оппозиции (Архипов, 2007). Власть, оказавшись в плену иллюзии «всеобщего единения», поощряла возникшие в обществе ксенофобские тенденции. Оппозиция довольно скоро и решительно отказала власти вправе представлять национальные интересы. Таким образом, патриотические чувства становились объектом манипуляции, а их «волновой» характер содержал в себе существенные политические риски.

С.В. Тютюкин видел в патриотических настроениях первых месяцев войны «кредит доверия» и «запас прочности», бездарно потраченные царским режимом, который оказался не в силах удовлетворить скромные, по мнению автора, пожелания Думы и общественных организаций: военные победы, обеспечение тыла всем необходимым, либерализацию внутренней политики и 
реформу государственного управления. Без уступок со стороны самодержавия народный и буржуазный патриотизм таял, и крушение монархии становилось неизбежным (Тютюкин, 1999). В этом историк повторяет логику А.Ф Керенского, который также связывал патриотический подъем с ожиданиями либеральных реформ, включая предоставление автономии Польше, восстановление конституции Финляндии и отмену ограничений для евреев - отказ царского правительства от осуществления этих пунктов ограничивал и патриотические чувства, и помощь армии (Керенский, 1993: 90).

По-иному видит ситуацию Ф.А. Гайда. Он считает, что либерально-реформаторские круги, отстаивая свою политическую состоятельность в условиях ухудшения социально-экономического положения, были вынуждены идти на обострение политического кризиса, фактически используя национально-патриотическую риторику как политтехнологию, раздувая мифы о «темных силах возле трона» (Гайда, 2017: 16).

\section{4. Результаты}

Начало Первой мировой войны вызвало эмоциональный всплеск, наиболее наглядным проявлением которого были митинги и манифестации, молебны. Шествия под патриотическими лозунгами начались в провинциальных городах после того, как Австро-Венгрия объявила войну Сербии, а в России было введено в действие Положение о подготовительном к войне периоде (Белова, 2011: 159). Наивысший подъем манифестационной волны приходится на первые дни и недели войны. Молебнами и манифестациями нередко сопровождались проводы запасных, но столь же часто массовые шествия возникали в вечернее время - когда оканчивалась работа и спадала дневная жара. В уездных городах они собирали почти всех городских обывателей и первых лиц уезда (Молебен, 1914). Нередко оживление на улицах продолжалось до полуночи.

Исследователи отмечают «фестивальный», своеобразный празднично-развлекательный характер этих демонстраций. Так, в Орле первая патриотическая манифестация состоялась вечером 17 июля. Тысячная толпа с пением гимна собралась перед губернаторским домом. По просьбе собравшихся губернатор вынес портрет императора, с которым манифестанты отправились к дому вице-губернатора. По дороге к ним присоединился оркестр из городского сада. От вице-губернатора народ получил несколько национальных флагов и отправился сначала к зданию Городской думы, а оттуда - к казармам (ГАОО. Ф. 580. Ст. 1. Д. 5962. Л. 22).

Патриотические демонстрации отражали возросшую популярность государственной власти как центральной, так и местной. Массовые шествия имели своим ориентиром дом губернатора либо Городскую думу; их участники стремились быть возглавленными кем-либо из представителей администрации, а на манифестации 23 июля собравшиеся качали на руках орловского городского голову (Народная манифестация, 1914). «Единение народа и власти» фиксировали и верноподданнические телеграммы с приветствиями, поздравлениями по поводу одержанных побед в адрес императора и членов императорской фамилии. Важно, что такие телеграфные послания получали от высокопоставленных адресатов ответы с благодарностью, которые освещались местной прессой (Белова, 2011: 163). Таким образом, «информационное эхо» закрепляло тенденцию единения общества и власти.

В.Б. Аксенов считает патриотические шествия искусственно организованными полицией и правомонархическими объединениями (Аксенов, 2020: 48). Такой вывод он делает на основании того, что манифестирующая толпа располагала портретами императора и флагами. Однако, как было показано выше, этому факту можно найти и другое объяснение.

Признаком срежессированности патриотических выступлений В.Б. Аксенов считает и то, что позже манифестации не повторялись. На самом деле, Министерство внутренних дел просило местные власти для поддержания полного порядка впредь не допускать никаких демонстраций, шествий и манифестаций, кроме вызванных совершенно исключительными причинами (ГАОО. Ф. 851. Ст. 1. Д. 153. Л. 24).

Справедливости ради следует отметить, что мы действительно встречаем свидетельства об организованных властью манифестациях в Калуге, Малоярославце, Дмитровске-Орловском (Белова, 2011: 160; ГАОО. Ф. 580. СТ. 1. Д. 5962. Л. 111). Но нельзя отрицать и факта возникновения стихийных митингов, равно как нельзя отказывать в искренности патриотических чувств участникам митингов, инициированных властями.

В начале XX века патриотическое воспитание молодежи постепенно входило в практику образовательной политики, однако затрагивало преимущественно узкую социальную прослойку будущих военнослужащих (Merkulov et al., 2020). По мнению А.Б. Асташова, даже массовая армия не стала полноценным институтом модернизации, воспроизводя архаические структуры традиционной патриархальной культуры (Асташов, 2012: 37-39). Таким образом, в первые дни августа 1914 года влияние патриотической пропаганды было минимальным, а патриотическое воодушевление стихийным. В его основе лежали не рационально осмысленные, а эмоции воодушевления и даже эйфории от сопричастности ходу истории. Вслед за О.А. Суховой этот эмоционально-поведенческий 
комплекс можно оценить как механизм перехода структур повседневности из обыденно-стабильного в экстремальное состояние (Сухова, 2014: 106).

Показательно, что как современники, так и исследователи отмечают альтернативную патриотическому воодушевлению реакцию на объявление мобилизации и вступление России в войну, столь характерную для традиционной народной культуры, - плач, публичное выражение горя. Народ смотрел на войну как на природное бедствие или Божью кару, причины которых находятся вне человеческого понимания, а течение не зависит от воли человека.

Констатируя слабую оформленность и укорененность национально-патриотического чувства в народных массах, следует иметь в виду, что на протяжении нескольких столетий необходимость проливать кровь за Отечество была прерогативой привилегированного сословия аристократии и обособленного военного сословия. Переход к всеобщей воинской обязанности не был в полной мере осмыслен простонародьем, о чем может свидетельствовать сохранение на протяжении полувека рекрутских обрядов, предполагавших оплакивание призывника. В отсутствие социальных гарантий со стороны государства преобладающей в крестьянской среде была этика выживания, а отнюдь не самопожертвования. Можно согласиться с О.С. Поршневой, называющей «город» и «деревню» разными социокультурными мирами (Поршнева, 2010: 196).

Ярким явлением, сопровождавшим мобилизацию, стали беспорядки запасных, в которых приняло участие не меньше людей, чем в патриотических манифестациях. Первым, кто обратил внимание на волну беспорядков, прокатившихся по России во время мобилизации, был советский исследователь А.Б. Беркевич. В обширной статье, основанной на отчетах Департамента полиции, он привел данные о 247 погибших (Беркевич, 1947: 40). Дж. Санборн, основываясь на данных Управления по делам о воинской повинности МВД, сообщает о 225 жертвах (Санборн, 1999: 209). В любом случае не менее 100 из них стали жертвами подавления грандиозных беспорядков в Барнауле (к слову, еще около 200 человек тогда погибли в пожарах). А.Б. Беркевич однозначно оценивал бунты мобилизованных как антивоенные, а частично и антиправительственные.

Дж. Санборн рассматривает беспорядки во время мобилизации как публичное выражение несогласия с действиями власти со стороны людей, объединенных принадлежностью к национальному политическому сообществу, политической нации (Санборн, 1999: 210).

В.П. Булдаков увидел в основе «пьяных бунтов» неосознанную ненависть к старому «внутреннему врагу», издавна сковывавшему социальную энергию (Булдаков, 2014: 12).

Несмотря на разброс оценок, наиболее рациональным выглядит представление мотивов «пьяных бунтов» как желания мобилизованных провести предписанный традицией и сопровождавшийся принятием алкоголя ритуал проводов в армию (так называемые «рекрутские обряды», принадлежащие к группе переходных обрядов), а их практически повсеместное распространение свидетельствует о глубокой укорененности традиционного сознания в солдатской массе. Эти архаические мотивы глубже, чем объяснение беспорядков желанием солдат «расслабиться». Релаксирующая функция алкоголя (Сухова, 2014: 108; Аксенов, 2020: 116) не предполагает насильственных действий по ее реализации, тем более - сопряженных с человеческими жертвами.

Следует отметить, что на Урале и в Сибири заметным мотивом протестного движения запасных была тревога об оставляемых семьях (Беркевич, 1947: 14). Важный закон о наделении казенным пособием семейств призванных в армию был принят в 1912 году и впервые введен в действие с началом войны; неудивительно, что большинство мобилизованных не подозревали о его существовании. Разъяснительная работа и выдача пособия (которое выплачивалось за три месяца вперед) заметно смягчили остроту ситуации.

Случаи неповиновения призывников, нарушение ими прав собственности, даже столкновения с полицией не имели антивоенных черт. В отличие от более крупных беспорядков, имевших место за Уралом, в губерниях Европейской России представители власти и государственные учреждения не становились объектами агрессии.

Молебны, шествия и отправка телеграмм были символическими акциями, выражающими сопричастность происходящим событиям. Наряду с ними, поднимается волна «деятельного» патриотизма. Война дала импульс к появлению целого ряда социальных инноваций, традиционно определяемых понятием «благотворительная деятельность». Между тем их осуществление, как и реализация технологических и иных инноваций, требует от государства формирования комплекса институтов правового, финансового и социального характера, отвечающих национальным политическим и культурным особенностям (Stroeva, 2015: 207). В стратегической доктрине государства содержится система приоритетов и мер, направленных на содействие социальноэкономическому развитию страны, решению актуальных социальных проблем, укреплению национальной безопасности, причем значимость мер, реализуемых в конкретной области общественной жизни, детерминирована ее вкладом в решение социальных проблем (Golovina et al., 2017: 44-45). Необходимо отметить, что в пореформенный период развитие социальной сферы России осуществлялось во взаимодействии государства, местного самоуправления и институтов гражданского общества (Merkulov et al., 2017). Можно утверждать, что особая эмоциональная 
атмосфера начала войны стала существенным стимулом для нового этапа развития системы общественного призрения в России, характерной чертой которого стала интенсификация взаимодействия квазигосударственных (состоящих под высочайшим покровительством), общественных и частных благотворительных структур (Merkulov et al., 2021: 394, 399).

С первых же дней войны по всей стране начинается реализация множества инициатив, направленных на поддержку военных усилий государства. Организуются сборы пожертвований и вещей для госпиталей, продажа флажков союзных России стран, благотворительные спектакли и т.д. В роли системообразующих структур патриотической активности выступали благотворительные общества, в отношении которых государство все шире осуществляло функции целеполагания и организации.

Тема благотворительности тесно связана с темой волонтерского участия. Добровольческое движение не было ограничено так называемыми «охотниками» - добровольцами, уходившими на фронт. В тылу широкое распространение получили практики добровольчества, обусловленные запросами войны. Нередко они были связаны также с трансформацией социальных и гендерных ролей женщин привилегированного класса.

Например, в губернском Орле вскоре после начала войны Дамским комитетом были организованы курсы сестер милосердия. Уже через три дня запись на курсы была прекращена из-за наплыва желающих, причем на 40 мест было подано 200 заявлений. По многочисленным ходатайствам на курсы было зачислено 54 человека (Отчет, 1914: 8). При орловской общине сестер милосердия дважды организовывались бесплатные курсы сестер милосердия военного времени, подготовившие 160 человек (Доклады, 1917: 10).

В.Б. Аксенов последовательно отказывает благотворительности и добровольчеству в роли маркеров патриотизма, акцентируя эгоистические мотивы либо вынужденность таких действий (Аксенов, 2020: 49-52). Другие авторы соотносят их с гуманизмом и «нравственными чувствами» (Борщукова, 2008; Демидова и др., 2018). Следует отметить, что в основе благотворительности лежат чувства альтруизма и гуманизма, сочувствия ближнему и мотивы социальной солидарности. Исходя из этого, благотворительность эпохи Первой мировой войны не может быть однозначно объяснена только лишь патриотическими мотивами.

\section{5. Заключение}

Таким образом, мы видим, что феномен патриотического подъема первых месяцев войны в России был сложным, многообразным явлением, развивавшимся под воздействием целого ряда разнохарактерных факторов. Можно поддержать представления о неоднородной, гетерогенной структуре патриотических настроений. Универсальный концепт патриотизма не мог сложиться в Российской империи к началу Первой мировой войны, и в основе патриотических чувств россиян в первые месяцы войны лежали не идеи, а эмоции.

В европейских странах поддержка войны общественным мнением служила правительствам дополнительным аргументом эскалации дипломатического кризиса. В Российской империи вспышки массового стихийного энтузиазма в городах и молчаливое приятие ситуации деревней, отражавшие различия городской и сельской культуры, трактовались правительством как залог внутреннего мира и стабильности в тылу сражавшейся армии.

Можно предположить, что за время войны мировоззрение грамотных слоев эволюционировало от лояльно-патриотических к оппозиционно-патриотическим позициям, т.е. сместилось от безоговорочной моральной поддержки царя и правительства к идее «спасения Отечества» от внешнего и внутреннего врага. Эта интеллектуальная эволюция могла затрагивать образованные круги, имевшие сравнительно объективное представление о государственном устройстве; для крестьянских масс, живших в ином информационном пространстве, был характерен «стихийный», «инстинктивный» патриотизм, своеобразный взгляд на причины войны, ее характер и цели. Смысл происходящих событий было трудно сформулировать рационально даже на официальном уровне. Целевая и ценностно-смысловая структура участия России в войне была определена преимущественно через этические категории, задававшие геополитическому столкновению европейских империй морально-нравственную систему координат. Последовательное обращение к конкретным целям войны ввиду их неопределенности и трудности достижения было редким. Они не могли служить надежным мотивом для патриотической активности населения, и уже к началу 1915 года место славянской солидарности занимает самоценная категория Победы.

На динамику патриотических настроений непосредственно влияла рефлексия по поводу войны: априори она представлялась справедливой, кратковременной, победоносной. Однако война не оправдывала возлагавшихся на нее надежд, став затянувшейся и неудачной. Даже после начала войны ее причины и цели определялись официальной пропагандой в весьма туманных категориях «славы», «долга» и «чести». Мотивы «славянской солидарности» были в значительной степени обесценены Болгарией, разгромившей Сербию.

По мере продолжения войны фактором, напрямую влиявшим на патриотические чувства, становилась складывавшаяся под влиянием военных условий обстановка в тылу, т.е. повседневное 
окружение обывателя - тяжесть потерь и новых мобилизаций, рост цен и расстройство снабжения. Пространство патриотизма сжимается, он превращается в удобный аргумент в политической борьбе либеральной общественности с правительством. В широких массах патриотический этос самопожертвования сменяется рациональной стратегией выживания.

«Настроения 1914 года» следует рассматривать как самостоятельный феномен, а не этап эволюции патриотических настроений. Такой подход способен полнее раскрыть его нестабильный характер. Для июльско-августовского общественного подъема была характерна малая осведомленность участников о сути, характере, возможных последствиях разворачивавшихся глобальных процессов. Кроме того, следует иметь в виду, что громадная часть «простонародья» глубоко эмоционально реагировала на происходящее, однако эту реакцию нельзя охарактеризовать как проявление патриотических чувств. Таким образом, общим для российских «настроений 1914 года» был эмоциональный подъем, а оценка происходящего варьировалась в зависимости от социальной принадлежности индивида.

\section{Литература}

Аксенов, 2018 - Аксенов В.Б. «Патриотизм-1914»: от историографических противоречий к поиску психологической структуры // Историческая экспертиза. 2018. № 3. С. 232-252.

Аксенов, 2020 - Аксенов В.Б. Слухи, образы, эмоции. Массовые настроения россиян в годы войны и революции (1914-1918). М.: Новое литературное обозрение, 2020. 992 с.

Архипов, 2009 - Архипов И.Л. Патриотизм в период кризиса 1914-1917 годов // Звезда. 2009. № 9. C. 177-204.

Асташов, 2014 - Асташов А.Б. Русский фронт в 1914 - начале 1917 года: военный опыт и современность. М.: Новый Хронограф, 2014. 740 с.

Базанов, 2017 - Базанов С.Н. Первая мировая. От «войны до победного конца» к «миру любой ценой». М.: Академический проект, 2017. 218 с.

Белова, 2011 - Белова И.Б. Первая мировая война и российская провинция. 1914 - февраль 1917. М.: АИРО-ХХІ, 2011. 288 c.

Беркевич, 1947 - Беркевич А.Б. Крестьянство и всеобщая мобилизация в июле 1914 г.// Исторические записки. 1947. Т. 23. С. 3-43.

Борщукова, 2008 - Борщукова Е.Д. Частная благотворительность в России в условиях Первой мировой войны как элемент в выявлении патриотических настроений // Известия Российского государственного педагогического университета им. А.И. Герцена. 2008. № 84. С. 59-65.

Булдаков, 2014 - Булдаков В.П. Август 1914-го: природа «патриотических» настроений // Вестник Тверского государственного университета. Серия «История». 2014. № 4. С. 4-22.

Гайда, 2017 - Гайда Ф.А. Ответы на десять вопросов по истории Февральской революции // Россия в эпоху революций и реформ. Проблемы истории и историографии. 2017. Т. 5. С. 14-19.

ГАОО - Государственный архив Орловской области.

Демидова и др., 2018 - Демидова Е.И., Наумов С.Ю., Захаров А.В. и др. Гуманизм и патриотизм как факторы консолидации российского общества в годы Первой мировой войны // Bласть. 2018. № 4. С. 64-72.

Доклады, 1917 - Доклады Орловской губернской земской управы 51-му очередному Орловскому губернскому земскому собранию. Книга 1. Орел, 1917. 228 с.

Керенский, 1993 - Керенский А.Ф. Россия на историческом повороте: Мемуары. М.: Республика, 1993. 384 c.

Лейберов, 1999 - Лейберов И.П. Патриотические настроения, их проявления и угасание в годы первой мировой войны 1914-1918 гг. // Проблемы социально-экономической и политической истории России ХIX-XX веков. СПб.: Алетейя, 1999. С. 497-501.

Ленин, 1969 - Ленин В.И. О поражении своего правительства в империалистической войне // Полное собрание сочинений. Издание пятое. Т. 26. М.: Издательство политической литературы, 1969. C. 286-291.

Леонов, 2014 - Леонов М.И. Русская провинция в годы Первой мировой войны (1914 - февраль 1917) (Среднее Поволжье и Заволжье) // ХХ век и Россия: общество, реформы, революции. 2014 . № 2. C. 129-142.

Лор, 2012 - Лор Э. Русский национализм и Российская империя: кампания против «вражеских подданных» в годы Первой мировой войны. М.: Новое литературное обозрение, 2012. $301 \mathrm{c.}$

Молебен, 1914 - Молебен о даровании победы русскому оружию в Болхове // Орловский Вестник. 1914. 10 августа.

Народная манифестация, 1914 - Народная манифестация и молебен в Орле // Орловский Вестник. 1914. 24 июля.

Отчет, 1914 - Отчет Орловского Дамского комитета попечения о больных и раненых воинах за время с открытия его действий по 1 ноября 1914 года. Орел: Әлектрическая типография губернского правления, 1914. 33 с. 
Поршнева, 2010 - Поршнева О.С. «Настроение 1914 года» в России как феномен истории и историографии // Российская история. 2010. № 2. С. 185-200.

Поршнева, 2014 - Поршнева О.C. «Вторая Отечественная»: общественные настроения в Уральских губерниях в начальный период Первой мировой войны // Известия Уральского Федерального университета. Серия 2 «Гуманитарные науки». 2014. 33 (130). С. 10-21.

Санборн, 1999 - Санборн Д. Беспорядки среди призывников в 1914 г. и вопрос о русской нации: новый взгляд на проблему // Россия и Первая мировая война (Материалы международного научного коллоквиума). СПб.: Дмитрий Буланин, 1999. С. 202-216.

Семенова, 2011 - Семенова Е.Ю. Патриотические и антипатриотические настроения горожан Поволжья в Первую мировую войну (1914 - начало 1918 гг.) // Современные проблемы науки и образования. 2011. № 5. С. 141-149.

Сергеев, 2020 - Сергеев Е.Ю. Имперский патриотизм и кампания борьбы с «немецким засильем» в России 1914-1917 гг. // Культуры патриотизма в период Первой мировой войны (сборник статей). СПб.: Издательство Европейского университета в Санкт-Петербурге, 2020. С. 39-51.

Сироткина, 2007 - Сироткина И.Е. Российские психиатры на Первой мировой войне // Наука, техника и общество России и Германии во время Первой мировой войны. СПб.: Нестор-История, 2007. С. 326-344.

Сухова, 2014 - Сухова O.A. Социальные настроения и массовое социальное поведение провинциального общества в годы Первой мировой войны // XX век и Россия: общество, реформы, революции. 2014. № 2. С. 105-128.

Теория и методология..., 2014 - Теория и методология исторической науки: терминологический словарь / Отв. ред. А.О. Чубарьян. М.: Аквилон, 2014. 575 с.

Тютюкин, 1999 - Тютюкин С.В. Последний шанс императорской России // Куда идет Россия?.. Кризис институциональных систем: век, десятилетие, год. М.: Логос, 1999. С. 61-68.

Юдин, 2014 - Юдин Н.В. Патриотический подъем в начале Первой мировой войны: конструктивистский ракурс // Вестник МГИМО. 2014. № 4 (37). С. 17-25.

Golovina et al., 2017 - Golovina T.A., Merkulov P.A., Polyanin A.V. (2017). Strategic vectors of the development of the state support of youth entrepreneurship in Russia // Ekonomicheskaya Politika. 12(5): 42-61.

Merkulov et al., 2017 - Merkulov P.A., Sokolov V.V., Melnikov A.V. (2017). The Interaction of Civil Society Institutions and the State in the Sphere of Youth Policy Implementation: the Russian Experience of the Beginning of XX Century. // Bylye Gody. 43(1): 257-264.

Merkulov et al., 2020 - Merkulov P.A., Eliseev A.L., Aronov D.V. The Theory of Patriotism in PreRevolutionary Russia - from the First Steps to the Practice of Implementation // Bylye Gody. 2020. 55(1): 226-241.

Merkulov et al., 2021 - Merkulov P.A., Bukalova S.V., Leonova O.V. (2021). Development of the Social Assistance System in the Russian Empire during the World War I // Bylye Gody. 16(1): 392-403.

Stroeva et al., 2015 - Stroeva O.A., Mironenko N.V., Merkulov P.A. et al. (2015). Transformation of National Innovative Systems: Russian and Foreign Experience. // Asian Social Science. 11(20): $206-219$.

\section{References}

Aksenov, 2018 - Aksenov, V.B. (2018). «Patriotizm-1914»: ot istoriograficheskih protivorechij k poisku psihologicheskoj struktury ["Patriotizm-1914": from historiographical contradictions to the search for a psychological structure]. Istoricheskaya ekspertiza. 3: 232-252. [in Russian]

Aksenov, 2020 - Aksenov, V.B. (2020). Sluhi, obrazy, emocii. Massovye nastroeniya rossiyan v gody vojny i revolyucii (1914-1918). [Rumors, images, emotions. Mass moods of Russians in the years of war and Revolution (1914-1918)]. Moscow, Novoe literaturnoe obozrenie. 992 p. [in Russian]

Arhipov, 2009 - Arhipov, I.L. (2009). Patriotizm v period krizisa 1914-1917 godov [Patrioticism during the crisis of 1914-1917]. Zvezda. 9: 177-204. [in Russian]

Astashov, 2014 - Astashov, A.B. (2014). Russkij front v 1914-nachale 1917 goda: voennyj opyt i sovremennost'. [The Russian Front in 1914-early 1917: military experience and modernity]. Moscow, Novyj Hronograf. 740 p. [in Russian]

Bazanov, 2017 - Bazanov, S.N. (2017). Pervaya mirovaya. Ot «vojny do pobednogo konca» k «miru lyuboj cenoj» [The First World War. From "war to the bitter end" to "peace at any cost"]. Moscow, Akademicheskij proekt. 218 p. [in Russian]

Belova, 2011 - Belova, I.B. (2011). Pervaya mirovaya vojna i rossijskaya provinciya. 1914-fevral' 1917.

[The World War I and the Russian province. 1914-February 1917]. Moscow, AIRO-XXI 288 p. [in Russian]

Berkevich, 1947 - Berkevich, A.B. (1947). Krest'yanstvo i vseobshchaya mobilizaciya v iyule $1914 \mathrm{~g}$.

[The peasantry and general mobilization in July 1914]. Istoricheskie zapiski. 23: 3-43. [in Russian]

Borshchukova, 2008 - Borshchukova, E.D. (2008). Chastnaya blagotvoritel'nost' v Rossii v usloviyah Pervoj mirovoj vojny kak element $\mathrm{v}$ vyyavlenii patrioticheskih nastroenij [Private charity in Russia in the conditions of the First World War as an element in the identification of patriotic sentiments]. Izvestiya Rossijskogo gosudarstvennogo pedagogicheskogo universiteta im. A.I. Gercena. 84: 59-65. [in Russian] 
Buldakov, 2014 - Buldakov, V.P. (2014). Avgust 1914-go: priroda «patrioticheskih» nastroenij [August 1914: the nature of "patriotic" moods]. Vestnik Tverskogo gosudarstvennogo universiteta. Seriya: Istoriya. 4: 4-22. [in Russian]

Demidova i dr., 2018 - Demidova, E.I., Naumov, S.Yu., Zaharov, A.V. et al. (2018). Gumanizm i patriotizm kak faktory konsolidacii rossijskogo obshchestva v gody Pervoj mirovoj vojny [Humanism and patriotism as factors of consolidation of Russian society in the years of the World War I]. Vlast'. 4: 64-72. [in Russian]

Doklady, 1917 - Doklady Orlovskoj gubernskoj zemskoj upravy 51-mu ocherednomu Orlovskomu gubernskomu zemskomu sobraniyu. [Reports of the Orel Provincial Zemstvo Council to the 51st regular Orel Provincial Zemstvo Assembly] (1917). Oryol, 228 p. [in Russian]

Gajda, 2017 - Gajda, F.A. (2017). Otvety na desyat' voprosov po istorii Fevral'skoj revolyucii [Answers to ten questions on the history of the February Revolution]. Rossiya $v$ epohu revolyucij i reform. Problemy istorii $i$ istoriografii. 5: 14-19. [in Russian]

GAOO - Gosudarstvennyj arhiv Orlovskoj oblasti [State Archive of the Orel region].

Golovina et al., 2017 - Golovina, T.A., Merkulov, P.A., Polyanin, A.V. (2017). Strategic vectors of the development of the state support of youth entrepreneurship in Russia. Ekonomicheskaya Politika. 12(5): 42-61. Kerenskij, 1993 - Kerenskij, A.F. (1993). Rossiya na istoricheskom povorote: Memuary [Russia at the historical turn: Memoirs]. Moscow, Respublika. 384 p. [in Russian]

Lejberov, 1999 - Lejberov, I.P. (1999). Patrioticheskie nastroeniya, ih proyavleniya i ugasanie v gody pervoj mirovoj vojny 1914-1918 gg. [Patriotic moods, their manifestations and extinction in the years of the World War I 1914-1918]. Problemy social'no-ekonomicheskoj i politicheskoj istorii Rossii XIX-XX vekov. St Petersburg, Aletejya. Pp. 497-501. [in Russian]

Lenin, 1969 - Lenin, V.I. (1969). O porazhenii svoego pravitel'stva v imperialisticheskoj vojne [On the defeat of own government in the imperialist war]. Polnoe sobranie sochinenij. Izdanie pyatoe. T. 26. Moscow, Izdatel'stvo politicheskoj literatury. Pp. 286-291. [in Russian]

Leonov, 2014 - Leonov, M.I. (2014). Russkaya provinciya v gody Pervoj mirovoj vojny (1914 - fevral' 1917) (Srednee Povolzh'e i Zavolzh'e) [Russian province in the years of the World War I (1914-February 1917) (Middle Volga and Zavolzhye)]. XX vek i Rossiya: obshchestvo, reformy, revolyucii. 2: 129-142. [in Russian]

Lohr, 2012 - Lohr, E. (2012). Russkij nacionalizm i Rossijskaya imperiya: kampaniya protiv «vrazheskih poddannyh» v gody Pervoj mirovoj vojny [Russian nationalism and the Russian Empire: the campaign against "enemy subjects" during the World War I]. Moscow, Novoe literaturnoe obozrenie. 301 p. [in Russian]

Merkulov et al., 2017 - Merkulov, P.A., Sokolov, V.V., Melnikov, A.V. (2017). The Interaction of Civil Society Institutions and the State in the Sphere of Youth Policy Implementation: the Russian Experience of the Beginning of XX Century. Bylye Gody. 43(1): 257-264.

Merkulov et al., 2020 - Merkulov, P.A., Eliseev, A.L., Aronov, D.V. (2020). The Theory of Patriotism in Pre-Revolutionary Russia - from the First Steps to the Practice of Implementation. Bylye Gody. 55(1): 226-241.

Merkulov et al., 2021 - Merkulov, P.A., Bukalova, S.V., Leonova, O.V. (2021). Development of the Social Assistance System in the Russian Empire during the World War I. Bylye Gody. 16(1): 392-403.

Moleben, 1914 - Moleben o darovanii pobedy russkomu oruzhiyu v Bolhove [Prayers for the victory of Russian arms in Bolkhov]. Orlovskij Vestnik. 1914. 10 avgusta. [in Russian]

Narodnaya manifestaciya, 1914 - Narodnaya manifestaciya i moleben v Orle [The people's manifestation and prayer in Orel city]. Orlovskij Vestnik. 1914. 24 iyulya. [in Russian]

Otchyot, 1914 - Otchyot Orlovskogo Damskogo komiteta popecheniya o bol'nyh i ranenyh voinah za vremya s otkrytiya ego dejstvij po 1 noyabrya 1914 goda [Report of the Oryol Ladies Committee for the Care of sick and Wounded soldiers for the time from the opening of its operations to November 1, 1914]. Oryol: Elektricheskaya tipografiya gubernskogo pravleniya, 1914. 33 p. [in Russian]

Porshneva, 2010 - Porshneva, O.S. (2010). «Nastroenie 1914 goda» v Rossii kak fenomen istorii i istoriografii ["The Mood of 1914" in Russia as a Phenomenon of history and historiography]. Rossijskaya istoriya. 2: 185-200. [in Russian]

Porshneva, 2014 - Porshneva, O.S. (2014). «Vtoraya Otechestvennaya»: obshchestvennye nastroeniya v Ural'skih guberniyah v nachal'nyj period Pervoj mirovoj vojny ["The Second Patriotic War": public sentiment in the Ural provinces in the initial period of the First World War]. Izvestiya Ural'skogo federal'nogo universiteta. Seriya 2: Gumanitarnye nauki. 33 (130): 10-21. [in Russian]

Sanborn, 1999 - Sanborn, D. (1999). Besporyadki sredi prizyvnikov v 1914 g. i vopros o russkoj nacii: novyj vzglyad na problemu [Riots among conscripts in 1914 and the question of the Russian nation: a new look at the problem]. Rossiya $i$ Pervaya mirovaya vojna (Materialy mezhdunarodnogo nauchnogo kollokviuma). St. Petersburg, Dmitrij Bulanin. Pp. 202-216. [in Russian]

Semyonova, 2011 - Semyonova, E.Yu. (2011). Patrioticheskie i antipatrioticheskie nastroeniya gorozhan Povolzh'ya v Pervuyu mirovuyu vojnu (1914 - nachalo 1918 gg.) [Patriotic and anti-patriotic sentiments of the citizens of the Volga region in the First World War (1914 - early 1918)]. Sovremennye problemy nauki i obrazovaniya. 5: 141-149. [in Russian] 
Sergeev, 2020 - Sergeev, E.Yu. (2020). Imperskij patriotizm i kampaniya bor'by s «nemeckim zasil'em» v Rossii 1914-1917 gg. [Imperial patriotism and the campaign against the "German dominance" in Russia 1914-1917]. Kul'tury patriotizma v period Pervoj mirovoj vojny (sbornik statej). St. Petersburg, Izdatel'stvo Evropejskogo universiteta v Sankt-Peterburge. Pp. 39-51. [in Russian]

Sirotkina, 2007 - Sirotkina, I.E. (2007). Rossijskie psihiatry na Pervoj mirovoj vojne [Russian psychiatrists in the World War I]. Nauka, tekhnika i obshchestvo Rossii i Germanii vo vremya Pervoj mirovoj vojny. St Petersburg, Nestor-Istoriya. Pp. 326-344. [in Russian]

Stroeva et al., 2015 - Stroeva, O.A., Mironenko, N.V., Merkulov, P.A. et al. (2015). Transformation of National Innovative Systems: Russian and Foreign Experience Asian Social Science. 11(20): 206-219.

Suhova, 2014 - Suhova, O.A. (2014). Social'nye nastroeniya i massovoe social'noe povedenie provincial'nogo obshchestva $\mathrm{v}$ gody Pervoj mirovoj vojny [Social moods and mass social behavior of provincial society in the years of the World War I]. XX vek i Rossiya: obshchestvo, reformy, revolyucii. 2: 105-128. [in Russian]

Teoriya i metodologiya..., 2014 - Teoriya i metodologiya istoricheskoj nauki : terminologicheskij slovar' [Theory and methodology of historical science: terminological dictionary]. Otv. red. A.O. Chubar'yan (2014). Moscow: Akvilon, 575 p. [in Russian]

Tyutyukin, 1999 - Tyutyukin, S.V. (1999). Poslednij shans imperatorskoj Rossii [The last chance of Imperial Russia]. Kuda idet Rossiya? Krizis institucional'nyh sistem: vek, desyatiletie, god. Moscow: Logos. Pp. 61-68. [in Russian]

Yudin, 2014 - Yudin, N.V. (2014). Patrioticheskij pod"yom v nachale Pervoj mirovoj vojny: konstruktivistskij rakurs [Patriotic rise at the beginning of the World War I: a constructivist perspective]. Vestnik MGIMO. 4(37): 17-25. [in Russian]

\section{Патриотические настроения 1914 года как мобилизационный ресурс социальных трансформаций}

Павел Александрович Меркулов а, Светлана Владимировна Букалова а, *,

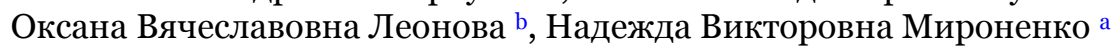

a Российская академия народного хозяйства и государственной службы при Президенте Российской Федерации Среднерусский институт управления - филиал, Российская Федерация

b Банковский колледж Среднерусского института управления - филиала РАНХиГС при Президенте Российской Федерации, Российская Федерация

Аннотация. Статья анализирует «патриотический подъем», сопровождавший вступление России в Первую мировую войну. Данный феномен общественного сознания и массового поведения рассматривается в рамках эволюции социально-политической сферы Российской империи предреволюционных лет, которая демонстрировала парадоксальную динамику перехода от видимого единения общества и власти к преобладанию антиправительственных настроений в условиях ожесточенного противостояния военной агрессии. Авторы констатируют слабость идейной основы патриотических настроений июля-августа 1914 года, что вело к преобладанию в них эмоциональной составляющей и определяло временную ограниченность этого явления. Содержание «настроений 1914 года» анализируется через их объективные внешние проявления: патриотические шествия, всплеск благотворительности и добровольчества, беспорядки мобилизованных. Каждое из этих явлений лишь в ограниченной степени может быть объяснено патриотической или «антипатриотической» мотивацией. Делается вывод о том, что начальный период Первой мировой войны в России сопровождался контрастными проявлениями общественной активности и противоположными эмоциями, отражавшими переход социума из стабильного в экстремальное состояние. Авторы приходят к выводу, что по своей природе «патриотический подъем» был самостоятельным явлением, что позволяет рассматривать его вне получившей распространение трехэтапной периодизации развития патриотических настроений в России в годы Первой мировой войны. Тем самым снимается проблема «вины» самодержавия, якобы не сумевшего использовать потенциал всеобщего патриотического воодушевления для мобилизации российского общества на ведение войны.

Ключевые слова: Российская империя, Первая мировая война, патриотизм, мобилизация, социальная политика, благотворительность, беспорядки мобилизованных.

\footnotetext{
* Корреспондирующий автор

Адреса электронной почты: stl1612@yandex.ru (С.В. Букалова), nio-ranepa57@mail.ru (П.А. Меркулов), oks980@rambler.ru (О.В. Леонова), mironenkonado@mail.ru (Н.В. Мироненко)
} 